\title{
Perkembangan Terapi Kanker Terkait Senyawa Terpineol, P53 dan Caspase 3
}

\author{
Maya E. W. Moningka \\ Bagian Fisika Fakultas Kedokteran Universitas Sam Ratulangi Manado \\ Email: mayaewm@gmail.com
}

\begin{abstract}
Recent anticancer drug development aims to molecular aspect with more specific target without harming healthy cells. Natural resources have been providing promising new anticancer drugs. Terpineol, an essential oil, is one of the anti-breast cancer candidates. Terpineol can be made from turpentine, which is non-wood product of pine tree latex. Alphaterpineol isolated from terpineol has an anticancer potency and has been proven to inhibit the growth and induce cancer cell death in vitro by inhibiting NF-kB. P53 is a tumor suppressor gene which triggers apoptosis when irreparable DNA damage occurs. Activity of p53 can be altered and/or inhibited by mutation and inactivation of other oncogenes. The main mechanism underlying apoptosis is caspase (cysteine aspartic acid protease) activity. One of the caspases responsible for apoptosis is caspase 3 . This caspase 3 can be activated by either intrinsic (mitochondrial signaling) or extrinsic (death ligand) mechanism; the latter involves caspase 8 and 9. Activated caspase 3 will execute the apoptosis inside the cells. Cytotoxic activity of $\alpha$-terpineol and its involvement in apoptosis, p53 expression, and caspase 3 activities in cancer cell cultures are still being investigated to determine their anticancer activities and the possibility of anticancer drug development.
\end{abstract}

Keywords: cancer therapy, terpineol, p53, caspase-3

\begin{abstract}
Abstrak: Pengembangan obat antikanker saat ini lebih ditujukan pada aspek molekuler dengan adanya target terapi yang lebih spesifik sehingga lebih aman untuk sel-sel tubuh yang normal. Dewasa ini, eksplorasi terhadap bahan alam untuk kandidat obat antikanker semakin dilirik. Minyak esensial terpineol merupakan salah satu bahan pada komposisi obat antikanker payudara. Terpineol dapat dibuat dari terpentin yang merupakan hasil hutan non kayu dari pohon pinus, dengan cara mengambil getahnya. Dari terpineol diisolasi senyawa $\alpha$-terpineol yang berpotensi sebagai antikanker serta telah terbukti dapat menghambat pertumbuhan dan menginduksi kematian sel tumor melalui mekanisme yang melibatkan inhibisi aktivitas NFкB. Gen p53 merupakan gen tumor supresor yang memicu terjadinya suatu kematian sel atau apoptosis bila terdapat kerusakan DNA dalam upayanya untuk mengatur proliferasi sel. Selain karena adanya mutasi gen p53, inaktivasi dapat terjadi oleh overekspresi onkogen yang nantinya berikatan dengan p53 dan menghambat kerja gen tersebut. Mekanisme utama yang juga mendasari terjadinya apoptosis ialah aktivitas cysteine aspartic acid protease (caspase). Salah satu caspase yang berperan dalam menginduksi apoptosis ialah caspase 3. Caspase ini dapat diaktifkan melalui mekanisme intrinsik (jalur mitokondrial) maupun ekstrinsik (death ligand), dengan bantuan caspase 8 dan caspase 9. Bila caspase 3 teraktifkan maka sebagai caspase eksekutor, akan melakukan tugasnya untuk mengapoptosis sel. Kajian aktivitas sitotoksik senyawa $\alpha$-terpineol terhadap suatu cell line, pengaruh senyawa tersebut terhadap proses apoptosis, ekspresi p53, dan aktivitas caspase 3 pada berbagai macam kanker masih terus diteliti dalam perkembangannya sebagai obat anti kanker.
\end{abstract}

Kata kunci: terapi kanker, terpineol, p53, caspase-3 


\section{Perkembangan Terapi Kanker}

Sel kanker didefinisikan sebagai sel dengan proliferasi yang berlawanan dari kontrol normalnya; oleh karena itu disebut neoplastik. Selain itu, sel kanker biasanya mampu untuk menyerang dan berkolonisasi di jaringan sekitar sehingga disebut malignan. Suatu sel dikatakan menjadi sel kanker bila telah mengabaikan sinyal eksternal dan internal yang meregulasi proliferasi sel, dapat menghindari apoptosis, secara genetik tidak stabil, bisa keluar dari jaringan awalnya (invasif), bisa bertahan hidup dan berproliferasi di jaringan lain/asing; oleh karena itu dikata-kan metastasik. ${ }^{1}$

Banyak hal dapat menyebabkan terjadinya kanker. Yang paling mudah untuk dipahami ialah hal yang menyebabkan terjadinya kerusakan DNA yang berakhir dengan mutasi. Mutagen yang bisa mengakibatkan kanker antara lain bahan kimia karsinogenik, virus, dan berbagai bentuk radiasi termasuk sinar UV dan radiasi ionisasi seperti sinar gamma dan partikel alpha yang keluar dari radioaktif. Faktor pendukung lainnya yaitu genetik, lingkungan, makanan, dan hormon. ${ }^{2}$

Setelah melalui berbagai penelitian dalam perkembangan terapi kanker, telah disepakati dua hal. Yang pertama, adanya 3 tipe gen kanker yang telah diketahui yaitu proto-onkogen, tumor supressor genes, dan faktor stabilitas genetik. Proto-onkogen memfasilitasi proliferasi sel, dan fungsi berlebihan oleh adanya mutasi pada gen ini menyebabkan terjadinya kanker. Tumor suppressor genes menghambat proliferasi sel, dan mutasi gen ini menyebabkan kehilangan fungsinya yang juga mengakibatkan kanker. Ketidakstabilan genetik memfasilitasi perkembangan dan progresivitas dari kanker. Jadi, kehilangan fungsi ataupun kelebihan fungsi karena mutasi gen yang mengatur stabilitas genetik, berperan penting dalam perkembangan dan progresivitas sel kanker. Teridentifikasinya gen-gen ini pada sel kanker mendukung kemajuan dalam penelitian terhadap perkembangan arah terapi kanker. Yang kedua yaitu telah diketahui karakteristik biokimiawi dari protein yang diproduksi oleh gen kanker; hal ini nantinya dapat dikembangkan dalam menjelaskan mekanisme molekuler suatu karsinogenesis. 1,3

Saat ini, obat antikanker yang dipakai untuk mematikan sel kanker bekerja dengan beberapa mekanisme, antara lain: 1) Berinteraksi langsung dengan DNA, efek sitotoksiknya lebih besar pada sel dengan tingkat proliferasi seluler tinggi; 2) Berinteraksi secara tidak langsung dengan DNA. Golongan obat ini disebut dengan antimetabolit. Antimetabolit merupakan senyawa dengan struktur mirip unsur metabolisme normal misalnya asam folat, purin dan pirimidin yang diperlukan dalam sintesis DNA; 3) Menghambat mitosis. Obat-obat ini dapat menghambat mitosis karena berikatan secara spesifik dengan tubulin sehingga mengganggu pembentukan benang spindel dan pembelahan sel; 4) Memengaruhi fungsi endokrin. Beberapa kanker membutuhkan hormon untuk pertumbuhannya, misalnya kanker ovarium dan kanker testis. Pertumbuhan kanker jenis tersebut dapat dihambat dengan memberikan hormon steroid atau antagonisnya. ${ }^{4}$

Permasalahan yang muncul dengan obat antikanker di atas ialah bahwa obatobat tersebut bersifat antiproliferatif bukan saja terhadap sel kanker namun juga terhadap sel normal. Karena sifat itulah maka obat-obat sitotoksik ini mempunyai indeks terapi dan selektivitas yang rendah. Selain itu, perkembangan saat ini ialah munculnya resistensi terhadap berbagai obat sitotoksik tersebut. ${ }^{5}$

Dewasa ini, dalam mengembangkan obat antikanker baru, mulai terjadi perubahan dari sekedar paradigma antiproliferatif ke arah yang lebih spesifik, yaitu lesi molekuler yang berperan dalam perkembangan dan keberlangsungan hidup sel-sel kanker. Tujuan akhir dari pengembangan target-target obat secara molekuler ini ialah untuk meningkatkan efikasi dan selektivitas terapi kanker sehingga obat antikanker mampu membunuh sel kanker namun tidak membahayakan sel-sel normal. ${ }^{6}$

Target obat antikanker yang saat ini banyak diteliti antara lain bekerja melalui:

1) Memacu apoptosis. Program apoptosis 
dapat dimanipulasi untuk memacu kematian sel, maka gen dan protein yang berperan di dalamnya dapat menjadi target pengembangan antikanker misalnya taksol; 2) Mengatur siklus sel dan mengendalikan checkpoint. Termasuk di sini ialah obatobat yang menginduksi p53, misalnya etoposid; 3) Menghambat faktor pertumbuhan dan transduksi sinyal yang ditimbulkannya. Contohnya ialah trastuzumab dan imatinib, yang berfungsi sebagai inhibitor tirosin kinase. ${ }^{5}$

\section{Senyawa $\alpha$-Terpineol}

Terpentin merupakan istilah yang dipakai secara umum untuk produk-produk berasal dari pengolahan getah pohon pinus yaitu hasil destilasi getah pinus. Terpentin berbentuk cair, berwarna jernih, serta merupakan pelarut yang kuat dengan ciri khas antara lain: berwarna jernih, tidak mengandung kotoran dan air, kompisisi $\alpha$ pinena dan $\beta$-pinena, dan memiliki bau yang khas. ${ }^{7}$

Fungsi terpentin ini awalnya hanya sebagai pelarut cat, sehingga harganya murah. Ternyata pada proses lebih lanjut dapat dihasilkan komponen $\alpha$-pinena dan $\beta$ pinena yang bernilai ekonomis tinggi dan menjadi bahan baku industri parfum, kapur barus, dan desinfektan. ${ }^{7}$

Terpineol merupakan parfum sintesis pertama yang dibuat secara komersil. Terpineol dapat dipergunakan dalam sabun, deterjen, dan berbagai formula parfum. ${ }^{8}$ Produksi terpineol dari terpentin sangat memakan waktu karena $\alpha$-pinena sangat sedikit larut dalam air, sehingga kontak antara $\alpha$-pinena dengan larutan asam (dalam air) sedikit sekali. Bahan $\alpha$-pinena sangat sensitif terhadap asam sehingga bisa menimbulkan berbagai reaksi samping yang sulit dihindari. ${ }^{8}$

Dalam alam, terdapat tiga bentuk isomer terpineol yaitu $\alpha$-terpineol, $\beta$ terpineol, dan $\gamma$-terpineol (Gambar 1). Banyaknya penelitian terhadap bahan alam sebagai obat antikanker membuat eksplorasi terhadap terpenoid dan turunannya semakin meluas. ${ }^{9}$

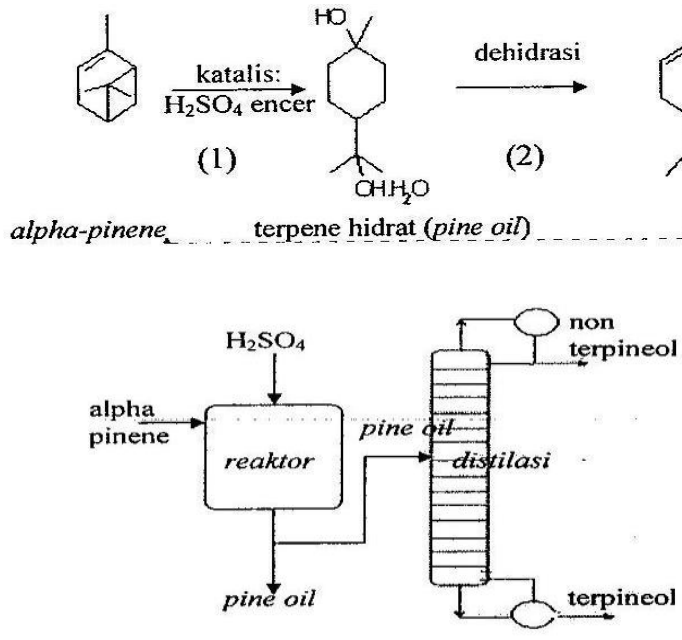

Gambar 1. Skema pembuatan terpineol. Sumber: Zinkle et al, $1980^{7}$

Telah diketahui adanya peran terpenoid dalam regulasi metabolisme isoprenoid dan signal transduksi, serta dapat menekan laju pertumbuhan sel, diferensiasi sel, multiplikasi, bahkan apoptosis. Efek terpenoid yang menguntungkan bagi kesehatan manusia dan pernah diuji ialah sebagai antimikroba, analgesik, anti kolesterolemia, masalah vaskuler, gangguan trakeal dan bronkhial, artritis, dan inflamasi, serta sebagai bahan kosmetik dan terapi kanker. ${ }^{9}$

Senyawa $\alpha$-terpineol dengan minimum inhibitory concentration (MIC) 0,250-1 $\mathrm{mg} / \mathrm{mL}$ atau $>2 \mathrm{mg} / \mathrm{mL}$ dalam beberapa penelitian terbukti bisa bersifat bakterisidal terhadap Escherichia coli. ${ }^{10-12}$ Sebagai antiproliferatif terhadap kanker payudara, senyawa $\alpha$-terpineol mampu menekan proliferasi sel akan tetapi bahan kimia citronelal yang lebih tinggi dalam persentase penekanan proliferasi sel kanker payudara. Pada erythroleukemic cell, nampaknya efek antiproliferatif yang ditimbulkan bermakna terhadap sel-sel tersebut. ${ }^{13}$ Pada sel-sel buccal cavum oris, senyawa $\alpha$-terpineol berperan menurunkan inflamasi (sebagai anti inflamasi). ${ }^{14}$ Penelitian oleh Park et $\mathrm{al}^{15}$ mendapatkan efek antifungal terhadap Trichopyton mentagrophyte dengan pemberian senyawa turunan terpineol yaitu eugenol, citral, nerolidol, dan $\alpha$-terpineol. Dalam perkembangan terapi kanker, senyawa $\alpha$-terpineol 
terbukti mampu sebagai antikanker yang potensial karena mampu menekan sinyal faktor transkipsi NF-кB pada small cell lung carcinoma. Kemampuan menghambat NF-кB dapat menyebabkan sel tumor berhenti berproliferasi, mati, atau menjadi lebih sensitif terhadap aksi agen anti tumor lainnya. ${ }^{13}$

\section{Apoptosis}

Istilah apoptosis pertama kali muncul pada tahun 1972, digunakan untuk menggambarkan sebuah pola baru dari kematian sel. Dalam proses apoptosis, sel mengalami perubahan karakteristik morfologik termasuk kondensasi dan fragmentasi inti, penyusutan sitoplasma, dan formasi yang telah terbentuk (apoptotic body) berisi fragmen inti sel sendiri dikelilingi oleh sitoplasma dan membran sel (Gambar 2).

A

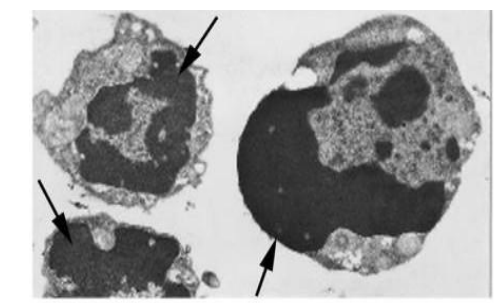

B

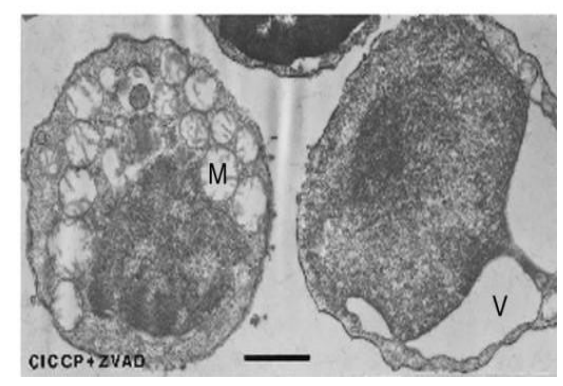

Gambar 2. A) Morfologi apoptosis; nekrosis. Sumber: Hirsch et al, $1997^{17}$

Sel yang telah mengalami apoptosis secara cepat difagositosis oleh sel fagositik termasuk makrofag. Hal ini berbeda dengan nekrosis, yang merupakan bentuk lain kematian sel disebabkan oleh cedera non spesifik seperti trauma tumpul, pajanan toksin, atau kehilangan pasokan darah. Pada nekrosis, sel membengkak dan kemudian ruptur. Pelepasan konten sitoplasmik mencetuskan terjadinya respon inflamasi yang tidak terjadi pada proses apoptosis. ${ }^{16}$
Secara umum apoptosis melibatkan dua mekanisme, yaitu jalur intrinsik (mitochondrial pathway) dan jalur ekstrinsik (death receptor pathway). ${ }^{17-19}$

\section{Jalur Intrinsik}

Jalur ini merupakan hasil peningkatan permeabilitas mitokondria dan pelepasan molekul pro-apoptosis ke dalam sitoplasma, tanpa peran death reseptor. Faktorfaktor pertumbuhan (growth factor) dan sinyal-sinyal survival memicu produksi protein-protein antiapoptosis anggota keluarga Bcl-2, yang terpenting ialah Bcl-2 dan Bcl-XL. Protein-protein anti apoptosis ini terletak pada membran mitokondria dan sitoplasma. Bila sel kehilangan sinyal survival atau terpapar suatu stres, Bcl-2 dan atau Bcl-XL hilang dari membran mitokondria dan digantikan protein pro apoptosis seperti Bak, Bax, dan Bim. Bila level Bcl-2 atau Bcl-XL turun, permeabilitas membran mitokondria meningkat dan beberapa protein yang dapat mengaktivasi kaskade caspase keluar, antara lain sitokrom c yang berperan dalam respirasi mitokondria dan apoptosis-inducing factor (AIF) suatu flavoprotein mitokondria. Di dalam sitoplasma, sitokrom c berikatan dengan apoptotic protease activating factor 1 (Apaf-1). ${ }^{18}$

Sitokrom C, Apaf-1 bersama dengan deoxy-ATP (dATP) mengaktivasi procaspase-9 menjadi caspase-9. Sitokrom c, Apaf-1, dATP, dan caspase-9 bersamasama membentuk kompleks apoptosom. Apaf-1 adalah protein multidomain yang mempunyai $N$-terminal caspase-recruitmen domain (CARD), sebagai tempat berikatan dengan caspase-9. Selanjutnya kompleks apoptosom akan mengaktivasi procaspase-3 menjadi caspase-3 sedangkan AIF akan mengikat IAP sehingga IAP tidak akan menghambat aktivasi kaskade caspase. ${ }^{19}$

Jalur ini dapat dihambat oleh proteinprotein anggota keluarga inhibitor apoptosis protein (IAP), beberapa prototipnya ialah X-linked IAP (XIAP), c-IAP1, dan cIAP2. XIAP, c-IAP1, dan c-IAP2 dapat menghambat aktivasi procaspase- 9 menjadi caspase-9 maupun pada aktivasi pro- 
caspase-3 menjadi caspase-3 namun ketiganya dapat dihambat oleh second mitochondrial activator caspase (Smac)/ direct IAP binding protein with low pI (DIABLO), suatu protein dari mitokondria yang dilepaskan bersama sitokrom c yang mengikat XIAP, c-IAP1, dan c-IAP2 untuk melepaskan hambatannya pada caspase. ${ }^{19}$

\section{Jalur Ekstrinsik}

Jalur ini diinisiasi dengan adanya ikatan pada death receptor di permukaan sel. Death receptor termasuk dalam keluarga tumor necrosis factor, yang mempunyai bagian dalam sitoplasma dikenal sebagai death domain (karena pentingnya peran dalam pengiriman sinyal apoptosis). Death receptor yang banyak dikenal ialah tumor necrosis factor receptor type 1 (TNFR1), Fas (CD59), TNF-related apoptosisinducing ligand receptor-1 dan -2 (TRAILR1 dan TRAIL-R2). Bila Fas berikatan dengan Fas ligan (FasL), tiga atau lebih molekul Fas bersama, kemudian death domain-nya pada sitoplasma bersama-sama berikatan dengan protein adapter yang juga mempunyai death domain yaitu Fasassociated death domain (FADD). Selanjutnya, FADD akan berikatan dengan procaspase-8. Procaspase-8 ini berikatan dengan FADD pada N-terminal yang dikenal dengan death effector domain (DED). Procaspase-8 dan FADD membentuk kompleks the death-inducing signaling complex (DISC). Dalam DISC ini pro caspase- 8 teraktivasi menjadi caspase- 8 , selanjutnya casapse- 8 akan mengaktivasi kaskade caspase, yaitu dengan mengaktivasi procaspase-3 menjadi caspase-3. Jalur ekstrinsik ini dapat dihambat oleh FLICEinhibitory protein (FLIP). FLIP menghambat dengan cara mengikat procaspase8 , sehingga procaspase- 8 tidak dapat teraktivasi. Beberapa virus memroduksi protein FLIP ini, untuk melindungi sel yang terinfeksi virus dari apoptosis yang dimediasi Fas. ${ }^{20-21}$

Dalam mekanisme apoptosis, mungkin yang terpenting ialah peran anggota keluarga cystein protease with aspartatespecificity (caspase). Terdapat dua kelom- pok caspase, yaitu inisiator dan efektor. Caspase inisiator akan mengaktivasi caspase efektor. Yang termasuk caspase inisiator yaitu caspase 8, 9, dan 10, sedangkan yang termasuk caspase efektor yaitu caspase 3,6 dan $7 .^{21}$

\section{Gen Tumor Supresor p53 dan Caspase 3}

Tumor supressor gen p53 merupakan suatu protein yang berperan penting dalam pengendalian pertumbuhan sel, repair DNA, dan apoptosis. Telah diketahui bahwa p53 bekerja sebagai rem penting yang dapat menginduksi sel tetap berada dalam fase G1 dan dapat memacu apoptosis setelah terjadi kerusakan DNA, baik dengan menahan pembelahan sel hingga kerusakan dapat diperbaiki atau dengan membuat sel bunuh diri bila kerusakan DNA tidak dapat diperbaiki. Adanya mutasi p53 pada sebagian besar kanker menunjukkan bahwa p53 berperan penting dalam karsinogenesis. Jadi peran p53 sangat penting dalam melindungi sel dari kerusakan genetik yang sifatnya fatal. ${ }^{22}$

Gen p53 terletak pada lengan pendek kromosom 17 dan mengkode protein inti dengan berat molekul 53.000 dalton (53 $\mathrm{kD}$, sehingga disebut dengan p53). Protein p53 ini merupakan faktor transkripsi dan regulator siklus sel yang sangat penting. Bila p53 mengalami inaktivasi, baik karena mutasi atau karena onkogen dari DNA virus penyebab tumor, maka regulasi siklus sel akan terganggu. ${ }^{22}$

Setelah terjadi stres pada sel, terjadi signaling kaskade yang melibatkan protein kinase yang tergantung DNA sehingga p53 mengalami fosforilasi dan menjadi stabil lepas dari protein MDM. Adanya stabilisasi terhadap p53 ini menyebabkan tertahannya siklus sel pada fibroblas yang tidak bertransformasi, namun di sisi lain menyebabkan apoptosis pada sel yang bertransformasi. Perilaku p53 ini berperan penting dalam regulasi tumor-selective death. ${ }^{22}$

Peran p53 dalam apoptosis diinduksi oleh stres yang dialami sel, misalnya kerusakan sel, stres oksidatif, dan obat kemoterapi. Beberapa obat antineoplastik menginduksi apoptosis dengan mengakti- 
vasi p53, misalnya cisplatin dan etoposid, juga radiasi ( $\gamma$ dan UV). Aktivasi p53 sebagai respon terhadap pemberian obat kemoterapi terjadi melalui dua peran, yaitu sebagai komponen penting checkpoint seluler dan sebagai mediator dalam apoptosis. Fungsi checkpoint p53 salah satunya diperankan oleh p21WAF1/CIP1 sehingga sel tetap berada pada fase G1 (G1/S arrest), sedangkan mediator apoptosis diperankan oleh bax. ${ }^{23,24}$

Berdasarkan fungsinya, caspase dibagi menjadi dua yaitu caspase inisiator dan caspase eksekutor atau efektor. Caspase 3 termasuk dalam caspase eksekutor, dimana pengaktifannya dari caspase inisiator, caspase 8 dan caspase 9. Salah satu ciri sel kanker ialah mampu menghindari apoptosis. Aktivasi apoptosis baik jalur ekstrinsik maupun jalur intrinsik akan berujung pada aktivasi caspase-3 sebagai caspase eksekutor. Bila caspase-3 telah teraktivasi, terjadi determinasi, kematian sel tidak terhindar, dan terjadi apoptosis. ${ }^{25}$

Oleh karena masih banyaknya efek samping pengobatan radioterapi, saat ini dikembangkan berbagai obat antikanker yang baru. Pengembangan obat antikanker saat ini lebih ditujukan pada aspek molekuler dengan adanya target terapi yang lebih spesifik sehingga lebih aman untuk sel-sel tubuh yang normal. ${ }^{5}$ Akhir-akhir ini, eksplorasi terhadap bahan alam untuk kandidat obat antikanker semakin dilirik. Minyak esensial terpineol merupakan salah satu bahan yang ada pada komposisi obat antikanker payudara. ${ }^{26}$ Terpineol dapat dibuat dari terpentin yang merupakan hasil hutan non kayu dari pohon pinus, dengan cara mengambil getahnya. Dari terpineol kemudian diisolasi senyawa $\alpha$-terpineol yang berpotensi sebagai antikanker, yang telah terbukti dapat menghambat pertumbuhan dan menginduksi kematian sel tumor melalui mekanisme yang melibatkan inhibisi aktivitas $\mathrm{NF}_{\kappa} \mathrm{B} .^{13}$

\section{SIMPULAN}

Sampai saat masih terus dilakukan penelitian lanjut terkait p53 yang memicu terjadinya apoptosis bila terdapat kerusakan
DNA. Selain karena mutasi pada gen p53, inaktivasi dapat terjadi oleh overekspresi onkogen yang nantinya berikatan dengan p53 dan menghambat kerja gen tersebut.

Mekanisme utama yang juga mendasari terjadinya apoptosis ialah aktivitas caspase. Salah satu caspase yang berperan dalam menginduksi apoptosis ialah caspase 3, yang dapat diaktifkan melalui mekanisme intrinsik (jalur mitokondrial) maupun ekstrinsik (death ligand), dengan bantuan caspase 8 dan caspase 9. Bila caspase 3 teraktifkan maka sebagai caspase eksekutor, akan melakukan tugasnya mengapoptosis sel.

Kajian aktivitas sitotoksik senyawa $\alpha$ terpineol terhadap suatu cell line dan pengaruh senyawa tersebut terhadap proses apoptosis serta ekspresi p53 juga aktivitas caspase 3 pada berbagai macam kanker masih terus diteliti dalam perkembangannya sebagai obat anti kanker.

\section{DAFTAR PUSTAKA}

1. Alberts B, Johnson A, Lewis J, Raff M, Roberth K. Molecular Biology of the Cell (5th ed). New York: Garland Science, 2008.

2. Cumming JH, Bingham SA. Diet and the prevention of cancer. Brimed J. 1998; 317(12):1636-40.

3. Sander M, Trump BF, Harris CC, Tennant RW. The 20th Aspen Cancer Conference: Mechanisms of Toxicity, Carcinogenesis, Cancer Prevention and Cancer Therapy. Mol Carcinog. 2008; 47(9):707-32.

4. Chabner BA, Ryan DP, Paz-Ares L, GarciaCarbanero R, Calabresi P. Antineoplastic agents. In: Gilman AG, Hardman JG, Limbird LE, editors. Goodman \& Gillmans The Pharmacological Basis of Therapeutics (10th ed). New York: McGraw-Hill Companies, Inc., 2001; p. 1389-459.

5. Workman P. New Drug targets for genomic cancer therapy: successes, limitations, opportunities and future challenges. Current Cancer Drug Targets. 2001; 1:33-47.

6. Balis FM. Evolution of anticancer drug discovery and the role of cell based screening. J Nat Cancer Institute. 2002; 
94(2):78-9.

7. Zinkel DF, Russel, J. Naval Stores: Production, Chemistry and Utilisation. New York: Pulp Chemical Association, 1980.

8. Roman-Aguirre M, Torre-Saenz LD, Flores WA, Robau-Sanchez A, Elguezabal AA. Synthesis of terpineol from $\alpha$ pinene by homogeneous acid catalysis. Catalysis Today. 2005;107/108:310-4.

9. Harrewijn P, Van Oosten AM, Piron PGM. 2001. Natural Terpenoids as Messenger. Dordrecht: Kluwer Academic Publisher, 2001; p. 147-73.

10. Bakkali F, Averbeck S, Averbeck D, Idaomar M. Biological effects of essential oils - a review. Food Chem Toxicol. 2007;46:446-75.

11. Oyedemi SO, Okoh AI, Mabinya LV, Pirochnva G, Afolayan AJ. 2008. The proposed mechanism of bactericidal action of eugenol, $\alpha$ terpineol and $\gamma$ terpinene against Listeria monocytogenes, Streptococcus pyogenes, Proteus vulgaris and Escherichia coli. Afr J Biotechnol. 2008;8(7):1280-6.

12. Martin DM, Bohlmann J. Identification of Vitis vinifera $\alpha$-Terpineol synthase by silico screening of full length cDNA ESTs and functional characterization of recombinant terpene synthase. Phytochemistry. 2004;65:1223-9.

13. Hassan SB, Muhtasib HG, Goransson H, Larsson R. 2010. Alpha terpineol: a potential anticancer agent which acts through supressing NFKB signalling. Cancer Res. 2010;30:1911-20.

14. Held S, Schieberle P, Somoza V. Characterization of $\alpha$-terpineol as an anti-inflammatory component of orange juice by in vitro studies using oral buccal cells. J Agric Food Chem. 2007;55:8040-6.

15. Park MJ, Gwak KS, Yang I, Kim KW, Jeung EB, Chang JW, et al. 2009. Effect of citral, eugenol, nerolidol and $\alpha$-terpineol on the ultrastructural changes of Tricophyton mentagrophytes. Fitoterapia. 2009;80: 290-6.

16. Blatt NB, Glick GD. Signaling pathways and effector mechanism pre-programmd cell death. Bioorganic \& Medicinal Chemistry. 2000;9:1371-84.

17. Hirsch T, Marchetti P, Susin SA, Dalaporta B. Oncogene. 1997;15: 1573.

18. Bremer E, Dam GV, Kroesen BJ, Leij de L, Helfrich W. Targeted induction of apoptosis for cancer therapy: current progress and prospect. Trends Mol Med. 2006;12(8):382-93.

19. Scott FL, Jean-Bernard D, Riedl SJ, Shin H, Renatus M, Salvensen GS. XIAP inhibits caspase-3 and -7 using two binding sites: evolutionarily conserved mechanism of IAPs. The EMBO Journal. 2005;24:645-55.

20. Kumar V, Abbas AK, Fusto N. Robbins and Contran. Pathology Basic of Disease (7th ed). Pennsylvania; Elsevier Saunders, 2005.

21. Haunstetter A, Izumo S. 2000. Apoptosis. Chapter 52.

22. Wang Z, Sun Y. Targeting p53 for novel anticancer therapy. Transl Oncol. 2010;3(1):1-12.

23. Levine AJ, Oren M. The first 30 years of p53: growing ever more complex. Nat Rev Cancer. 2009;9(10):749-58.

24. MacFarlane M, William AC. Apoptosis and disease: a life or death decision. EMBO Rep. 2004;5(\&):674-8.

25. Yi HC, Yuan J. The Jekyll and Hyde functions of caspase. Dev Cell. 2009;16(1):21-34.

26. Brentwood TN, Franklin TN. 2004. Cancer Treatment Composition and Method Using Natural Plant Essential oils, United States Patent 6812258

27. Rugo HS. Cancer in Current Medical Diagnosis and Treatment (45th ed). Tierney LM, McPhee SJ, Papadakis MA. New York: McGraw-Hill, 2006 